\title{
Investigating high zircon concentrations in the fine fraction of stream sediments draining the Pan-African Dahomeyan Terrane in Nigeria
}

Roger M. Key ${ }^{\mathrm{a}}$, Christopher C. Johnson ${ }^{\mathrm{b}}$, Matthew S.A. Horstwood ${ }^{\mathrm{c}}$, Dan J. Lapworth ${ }^{\mathrm{d}}$, Katherine V. Knights ${ }^{\mathrm{b}}$, Simon J. Kemp ${ }^{\mathrm{b}}$, Michael Watts ${ }^{\mathrm{b}}$, Martin Gillespie ${ }^{\mathrm{a}}$, Michael Adekanmi $^{\mathrm{e}}$, Tunde Arisekola ${ }^{\mathrm{e}}$

${ }^{a}$ British Geological Survey (BGS), Edinburgh, EH45 9ER, UK (Roger Key:rmk@bgs.ac.uk; Martin Gillespie:mrg@bgs.ac.uk)

${ }^{b}$ British Geological Survey (BGS), Keyworth, Nottinghamshire, NG12 5GG, UK (Chris

Johnson:ccj@bgs.ac.uk; Kate Knights: kate.knights@gsi.ie; Simon Kemp: sjk@bgs.ac.uk;

Michael Watts: mwatts@bgs.ac.uk;

${ }^{c}$ NERC Isotope Geosciences Laboratory, Keyworth, Nottinghamshire, NG12 5GG, UK

(mash@bgs.ac.uk)

${ }^{d}$ British Geological Survey, Wallingford, Oxfordshire,OX10 8BB (djla@bgs.ac.uk)

${ }^{e}$ Nigerian Geological Survey Agency (NGSA), 31 Shettima A Munguno Crescent, Abuja,

Nigeria (arisekola tunde:arisekolatunde@yahoo.com; Michael Adekanmi:

michaeladekanmi@yahoo.com)

\begin{abstract}
Sixteen hundred stream sediments $(<150 \mu \mathrm{m}$ fraction) collected during regional geochemical surveys in central and SW Nigeria have high median and maximum concentrations of $\mathrm{Zr}$ that exceed corresponding $\mathrm{Zr}$ concentrations found in stream sediments collected from elsewhere in the World with similar bedrock geology. X-ray diffraction studies on a sub-set of the analysed stream sediments showed that $\mathrm{Zr}$ is predominantly found in detrital zircon grains. However, the main proximal source rocks (Pan-African 'Older Granites' of Nigeria and their Proterozoic migmatitic gneiss country rocks) are not enriched in zircon (or $\mathrm{Zr}$ ). Nevertheless, $\mathrm{U}-\mathrm{Pb} \mathrm{LA}-\mathrm{ICP}-\mathrm{MS}$ dating with cathodoluminescence imaging on detrital zircons, both from stream sediment samples and underlying Pan-African 'Older Granites' confirms a local bedrock source for the stream sediment zircons. A combination of tropical/chemical weathering and continuous physical weathering, both by 'wet season' flash flooding and 'dry season' unidirectional winds are interpreted to have effectively broken down bedrock silicate minerals and removed much of the resultant clay phases, thereby increasing the $\mathrm{Zr}$ contents in stream sediments. The strong correlation between winnowing index (Th/ $\mathrm{Al})$ and $\mathrm{Zr}$ concentration across the study area support this interpretation. Therefore, 'anomalous' high values of $\mathrm{Zr}$, as well as other elements concentrated in resistant 'heavy' minerals in Nigeria's streams may not reflect proximal bedrock concentrations of these elements. This conclusion has important implications for using stream sediment chemistry as an exploration tool in Nigeria for primary metal deposits associated with heavy minerals.
\end{abstract}

Keywords: Nigeria, Stream sediments, Geochemistry, Zircon, Zirconium, Pan-African

\section{Introduction}


Teams from the Geological Surveys of the UK, Nigeria and Finland completed a regional geochemical mapping campaign in central and SW Nigeria in 2010 as part of a national geochemical mapping project (Key et al., 2010; Lapworth et al., 2012). The mapped area in central Nigeria $\left(160 \mathrm{~km} \times 160 \mathrm{~km}, 25600 \mathrm{~km}^{2}\right)$, referred to as the Minna Cell (Fig. 1), is one of the 5,000 Global Reference Network (GRN) cells, as defined by Darnley et al. (1995). A similar sized area (South-western Cell) in SW Nigeria covered parts of several GRN cells.

\subsection{Geological Setting}

Nigeria is underlain by Precambrian rocks within the Benin-Nigeria Shield (of the Dahomeyan Terrane) that separates the Archaean to Mesoproterozoic West African and Congo Cratons to the west and east of Nigeria respectively (Grant, 1967, 1969; Odeyemi, 1981; Black, 1980; Ajibade et al., 1987; Ajibade and Wright, 1989; Obaje, 2009). The Dahomeyan Terrane is part of the African network of Neoproterozoic-Ordovician PanAfrican Orogenic Belts, and is also referred to as the Trans-Saharan Belt. It is a collage of Neoproterozoic and older Precambrian rocks (interpreted as originally forming parts of continental fragments, island arcs and intervening basins) formed during collision between various lithospheric plates, including the West African and Congo Cratons (Burke and Dewey, 1972; Dada, 2006). The Trans-Saharan Belt is divided into an Eastern Terrane, and a Western Terrane that includes the Minna and South-western Cells.

The Western Terrane comprises three major lithological units - migmatitic gneisses, supracrustal/schist belts and Pan-African plutonic rocks (Russ, 1957; Hockey et al., 1963; Truswell and Cope, 1963; Jones and Hockey, 1964; Dempster, 1966; Grant, 1969; Odeyemi, 1981; Fitches et al., 1985; Ferré et al., 1996; Odigi, 2002; Ajibade et al., 2008). The migmatitic gneisses are lithologically similar to the ubiquitous 'grey gneisses' of many Precambrian metamorphic terranes and comprise variably migmatitic, quartzofeldspathic and amphibolitic gneisses that are also variably deformed to create a wide range of tectonic and 
metamorphic fabrics. They are poorly dated although ages in excess of $3.0 \mathrm{Ga}$ are reported (Ogezi, 1977; Kröner et al., 2001), as well as Palaeoproterozoic ages of about $2.0 \mathrm{Ga}$ (Rahaman and Lancelot, 1984) and Mesoproterozoic ages of about 1160 Ma (Grant et al., 1972; Ogezi, 1977).

The supracrustal/schist belts mainly occupy a broad NNE-SSW zone in the western half of Nigeria (Fig. 2) and extend westward into Benin and Togo. Component rocks are poorly dated--but most researchers are of the opinion that there were at least two and possibly three cycles (McCurry, 1971; Ogezi, 1977; Grant, 1978; Adekoya, 1996). The belts comprise a wide range of metasedimentary rocks including various pelitic schists and phyllites, quartzofeldspathic banded gneisses, quartzites, banded iron formation rocks and ferruginous quartzites, metaconglomerates, and dolomitic marbles and calc-silicate rocks. Metabasaltic, metadacitic, metarhyolitic and small ultramafic pods are also present (e.g. Shibayan, 1990). On the geological bases to the stream sediment geochemical maps the schist belt lithologies are grouped into the Metasedimentary and Metavolcanic Rocks unit (Fig. 3).

Within the Western Terrane there are many variably deformed ('syntectonic to late-tectonic') felsic, predominantly granodioritic intrusions. In Nigeria they are called Older Granites (Falconer, 1911) to distinguish them from the Jurassic Younger Granites of the Jos Plateau (Bowden and Kinnaird, 1984). The Older Granites give Neoproterozoic Pan-African ages of between about 740 and about 580 Ma (Jacobson et al., 1964; Tugarinov et al., 1968; Van Breemen et al., 1977; Lancelot and Rahaman, 1983; Tubosun et al., 1984; Ferré et al., 1998). Undeformed, late to post-Pan-African minor intrusions include muscovite, tourmaline, and rare earth element-bearing pegmatites; microgranites; syenites; gabbros and basalts; lamprophyres and felsites (e.g. Dada, 2006). An important feature characteristic of Nigeria's Pan-African Terrane is the presence of major ductile shear zones marked by discontinuous, mylonitised and silicified rocks and lenses of vein quartz (e.g. the Zungeru mylonites; 
Ajibade et al., 1979; Fig. 3). Later transcurrent brittle-ductile shear zones trend NNE-SSW and NE-SW and can be traced for hundreds of kilometres across western Nigeria (see Malomo, 2004; 2006).

The Younger Granites young southwards from Permo-Carboniferous intrusions at the NigerNigeria border, to late Jurassic intrusions in central Nigeria. They are dominantly syenitic to granitic in composition as anorogenic ring complexes with primary uranium-niobium, zinctin mineralisation (Wright, 1970). There are associated economic placer deposits of cassiterite (Bowden and Kinnaird, 1984). The main outcrop areas of the Younger Granites lies outside of the Minna and South-western Cells (Fig. 2) with only one small pluton identified in the extreme south-eastern part of the Minna Cell (Fig. 3).

There are also extensive sedimentary sequences and less common flood basalts of Mesozoic to Recent age that overlie the crystalline basement: in northern Nigeria in the Chad Basin and along the Niger border; in central Nigeria in the Benue Trough and Bida Basin (that covers the south-western part of the Minna Cell; Adeleye, 1974; Guiraud, 1990; Ajibade et al., 2008); as well as the coastal sedimentary strata and sediments of the Dahomey Basin of southern Nigeria (that covers the southern parts of the South-western Cell; Jones and Hockey, 1964), including the Niger Delta.

\subsection{Geography, soils and climate}

The study areas comprise moderately dissected peneplains with shallow drainage channels incising through tropical ferrallitic/fersiallitic soils (Fookes, 1997) into weathered bedrock. Granites as well as migmatitic gneisses form inselbergs and whalebacks that can rise to several hundred metres above the surrounding countryside. Rivers and streams form dendritic patterns and drain into the Niger River System (central Nigeria) or directly into the Atlantic Ocean (SW area) with local control by major fractures. Water flow is controlled by seasonal 
rains to vary from the extremes of flash flooding after torrential rain to stagnant water pools in dry water courses at the end of the 'dry season'. Floodwater is charged with fine (clayrich) sediment derived from weathered bedrock and tropical soils and seasonal flooding is clearly a major weathering process. The thickness of the weathered profile is variable with extremes of exposed, massive bedrock pavements and inselbergs with no soil cover to lateritic soil profiles at least several metres in thickness.

The climate of Nigeria is tropical with a wet season lasting from April until October and a hot, dry season from November until March. Daytime temperatures in the study areas vary from the low 20 s to the low $40 \mathrm{~s}{ }^{\circ} \mathrm{C}$, and there is a $\mathrm{S}-\mathrm{N}$ drop in total rainfall across Nigeria from about $2500 \mathrm{~mm}$ in the SW to about 1200-1500 mm in the Minna Cell. From December through February, the northeast trade winds blow strongly and often bring with them fine dust from the Sahara. These winds also scour unconsolidated surface material from Nigeria so that the dust-laden winds, known locally as the Harmattan, persistently create a dense haze across Nigeria. The stream sediment sampling took place between July and December 2009 when the water courses were generally gently flowing.

\subsection{Vegetation}

'Guinea savannah' vegetation covers the study areas with 'High or Rain forest' (Iloeje, 1991) confined to southern parts of the SW area. The Guinea savannah vegetation comprises typical combinations of tall grasses, scrub and scattered trees with denser tree cover along drainage channels. Commercial cocoa plantations are found in the SW area. The vegetation cover helps to prevent wind-scouring of unconsolidated soils during the wet season, but not during the dry season when the grasses die back.

\section{Sample selection and methodologies}

\section{$2.1 \quad$ Geochemistry}


Samples of stream sediment were taken as part of a regional mapping campaign. A total of 1307 samples were collected from the Minna Cell at an average density of 1:21 km², and 284 samples from the South-western Cell were collected at an average spacing of 1:90 $\mathrm{km}^{2}$. The different densities of the sample collection points reflect the perceived difference in prospectivity of the two areas: the South-western Cell is densely populated and with commercial farms and large urban centres that effectively sterilise large areas for mining. In contrast the Minna Cell is mainly undeveloped with fewer urban centres. However, the underlying geology in both areas is similar (Fig. 2). The catchment areas upstream of the collected stream sediment samples from both cells averaged between about 10 and $30 \mathrm{~km}^{2}$.

Samples of the $<150 \mu \mathrm{m}$ fraction of stream sediments were collected from low order streams that had gently flowing water. At every sample collection site, composite stream sediment samples were collected from at least five points within the active stream channel over a distance of about $50 \mathrm{~m}$. For details on sampling, sample preparation and analysis refer to Lapworth et al. (2012), these are also summarised in the supplementary material (Tables S1 and S2). A pan concentrate was also collected from each site from the $<2 \mathrm{~mm}->150 \mu \mathrm{m}$ material, to be examined as necessary as part of any later follow-up work.

The $<150 \mu \mathrm{m}$ samples were analysed in the British Geological Survey (BGS) laboratories by inductively coupled plasma mass spectrometry (ICP-MS) for 57 elements after 'total' dissolution using a sodium peroxide fusion, followed by a mixed acid dissolution. The results were plotted either as classified symbol plots or gridded images on geochemical maps plotted as ArcGIS map project files. The limit of detection for $\mathrm{Zr}$ based on $3 \times$ standard deviation of the blank fusion digests was $1 \mathrm{mgkg}^{-1}$.

The precision of $\mathrm{Zr}$ analysis is determined from the repeated analysis (30 times) of Nigerian secondary reference materials SRM1 and SRM2 calculated at mean $584 \pm 69 \mathrm{mg} \mathrm{kg}^{-1}, 12 \%$ relative standard deviation (RSD) and mean $2481 \pm 335 \mathrm{mg} \mathrm{kg}^{-1}, 14 \% \mathrm{RSD}$, respectively. 
Accuracy is determined from the analysis of primary reference materials (Table 1). The secondary reference materials are bulk sediment samples collected using the methodology described in this Section from two streams in the Minna Cell

\subsection{Mineralogy and optical microscopy}

Mineralogy of sixty seven stream sediment samples $(<150 \mu \mathrm{m})$ from both Cells was determined by X-ray diffraction (XRD), see supplementary material (Table S3) for details on XRD analysis and sample preparation. Following heavy media separation using lithium polytungstate, a variety of zircon crystal morphologies were observed by optical microscopy of the heavy mineral separate (Fig. 4). These vary from elongate, euhedral bladed crystals to anhedral, equant zircons. However, no rounded grains comparable to wind-transported zircons found in aeolian sediments were noted. The vast majority of examined zircon grains are colourless and unaltered. Only one or two grains had a pink coloration. Following heavy mineral separation, the mineralogy for a sub-set of twenty five samples from both the Minna and South-western Cells was determined by XRD.

\subsection{Geochronology}

Three granite samples (R-1303, 143-PP3 and 165-PP4) and 4 stream sediments (NIG-78, 164, 568, 1633) were selected for U-Pb geochronology (Fig. 3). Thin section examination of the three dated granites showed that zircon is only present in trace amounts as variably sized (up to about $300 \mu \mathrm{m}$ ), euhedral grains, occasionally enclosed in biotite where there are well developed radiation haloes. Based on their petrography, samples R-1303 and 143-PP3 are classed as a foliated hornblende-bearing biotite micromonzonite and sample 165-PP4 is classed as a biotite-bearing syenogranite.

All seven samples were dated using laser ablation ICP-MS at the Natural Environment Research Council (NERC) Isotope Geosciences Laboratory, BGS, Nottingham, UK. The 
detrital zircon samples and granite sample 143-PP3 were dated using multi-collector (MC-) ICP-MS whilst granite samples R-1303 and 165-PP4 were dated using single collector sector field (SC-SF-)ICP-MS. Methods and run conditions are detailed in Thomas et al. (2010). All samples were imaged using Cathodoluminscence (CL) prior to analysis. The CL images of zircon grains from the Minna Cell granites shows that they are mostly euhedral in shape with well developed terminations. They are internally concentrically zoned and locally cored and up to about $300 \mu \mathrm{m}$ in length (Fig. 5).

\section{Results}

\subsection{Stream sediment Zr geochemistry results}

Zirconium was found in unusually high concentrations in $<150 \mu \mathrm{m}$ stream sediments across the Minna and South-western Cells. Figure 6a shows a gridded image for $\mathrm{Zr}$ for the Minna Cell, the highest $\mathrm{Zr}$ values are mostly found in the SE quadrant where the bedrock is mainly migmatitic gneiss and Older Granite. The lowest $\mathrm{Zr}$ values (which remain above the crustal $\mathrm{Zr}$ average) occur in the north-western quadrant of the Cell with a pronounced NNE-SSW trend to the lower values parallel to the tectonic grain of underlying bedrock. The rocks in this area are strongly deformed within the Zungeru Mylonite Belt with flattened Older Granite plutons and mylonitic schist belt lithologies. In the South-western Cell (Fig. 6b) the highest $\mathrm{Zr}$ values again appear to be focused in areas with gneiss and granite bedrock and the area underlain by the Mesozoic and younger strata and sediments lacking the high $\mathrm{Zr}$ values.

For the whole Minna Cell (1307 samples), the median $\mathrm{Zr}$ concentration is $1300 \mathrm{mg} \mathrm{kg}^{-1}$ and maximum is $22800 \mathrm{mg} \mathrm{kg}^{-1}$ with corresponding concentrations of $290 \mathrm{mg} \mathrm{kg}^{-1}$ and $25800 \mathrm{mg}$ $\mathrm{kg}^{-1}$ for the South-western Cell (284 samples). Figure 7 shows notched box-plots for $\mathrm{Zr}$ concentrations $\left(\mathrm{mg} \mathrm{kg}^{-1}\right)$ found in stream sediments in Nigeria grouped by catchment geology. The local whole rock values (see Table 2), upper crust concentration (Wedepohl, 
1995) and European stream sediments (Salminen et al., 2005) are shown as horizontal lines. By comparison, $\mathrm{Zr}$ values in stream sediments determined by the Europe-wide FOREGS survey (Salminen et al., 2005) gave a median $\mathrm{Zr}$ value of $390 \mathrm{mg} \mathrm{kg}^{-1}$ and maximum of 9940 $\mathrm{mg} \mathrm{kg}^{-1}$. The $\mathrm{Zr}$ values in Nigeria's stream sediments are also higher than $\mathrm{Zr}$ concentrations in lithified sedimentary rock sequences reported by Rollinson (1993).

\subsection{Whole rock $\mathrm{Zr}$ concentrations}

There are very few published whole rock $\mathrm{Zr}$ values of Nigerian rocks from either central or south-western Nigeria. Published whole rock analyses of the metamorphic and igneous rocks of SW Nigeria record values of less than $1200 \mathrm{mg} \mathrm{kg}^{-1}$ for $\mathrm{Zr}$ (Table 2) and are generally similar to the average $\mathrm{Zr}$ value of upper crustal rocks of $240 \mathrm{mg} \mathrm{kg}^{-1}$ (Rollinson, 1993). Similar Zr values between 117 and 411 ppm (mean 171 ppm Zr) are recorded in analysed granitic rocks (13 analyses) from the Minna Cell, and between 205 and 570 ppm (mean 326 ppm Zr) for felsic metavolcanics (seven analyses) from the Birnin Gwari Schist Belt in the same Cell (Ajibade et al., 2008). XRF analyses of the three dated Older Granites from the Minna Cell gave 163, 217 and $242 \mathrm{mg} \mathrm{kg}^{-1} \mathrm{Zr}$ for samples R-1303, 143-PP3 and 165-PP4 respectively, i.e. within the range of values quoted by Ajibade et al. (2008) and similar to the $\mathrm{Zr}$ values of Older Granites from SW Nigeria.

\subsection{Stream sediment Zr mineralogy}

Summary XRD results from stream sediments $(<150 \mu \mathrm{m})$ are shown in Table 3 . This shows that they are dominated by quartz $(0.8-95 \%$ of the total grain count) and feldspar grains (3$33 \%$ ) with minor quantities of following minerals: pyroxene, amphibole, epidote, sillimanite, anatase, hematite, monazite ilmenite, mica and zircon (the latter up to 4.6\%).

XRD results of the heavy mineral fraction of the stream sediment samples $(<150 \mu \mathrm{m})$, from both cells are summarised in Table 4. This shows that the heavy mineral fraction is 
dominated by ilmenite and amphibole (median values of 40 and $15 \%$ ), quartz (median values of $8 \%$ ) as well as varying amounts of zircon, monazite and rutile. Zircon was found in all of the samples and comprised between $0.9-26 \%$ of the heavy mineral fraction. The only $\mathrm{Zr}$ bearing mineral identified by XRD is zircon, and the XRD concentrations of zircon shows a good correlation $\left(\mathrm{R}^{2}=0.91\right)$ with the $\mathrm{Zr}$ concentrations in the host sediments. Samples from streams with Older Granite-dominated geology generally have lower zircon concentrations compared to sediments from streams draining migmatitic gneiss. The morphologies of zircon grains vary from elongate, euhedral bladed crystals to anhedral, equant grains (Fig. 4). However, no rounded grains comparable to wind-transported zircons found in aeolian sediments were noted.

\section{$3.4 \quad U-P b$ zircon geochronology}

$\mathrm{U}-\mathrm{Pb}$ data for all dated samples is given in supplementary Table S4. Data for the three granite samples are illustrated in Figs. 8a-c and exhibit similar ages and data characteristics. All three samples show near zero-intercept Pb-loss with minor components of inheritance. Two data points of R-1303 are near concordant at 2.1Ga with other analyses exhibiting some inheritance. Omitting these analyses and others which indicate the effects of small amounts of common- $\mathrm{Pb}, 13$ data points form a cluster around concordia which regress to give an age of $607+/-$ 13Ma (MSWD =1.9, Fig. 8a). Samples 143-PP3 and 165-PP4 show similar data dispersions with regression results on all or selected data of $616+/-12 \mathrm{Ma}(\mathrm{MSWD}=1.9$, Fig. 8b) and $606+/-13 \mathrm{Ma}(\mathrm{MSWD}=1.9$, Fig. 8c) respectively. These ages lie within the previous range (740-580 Ma) of ages obtained for the Older Granites

Three of the four detrital zircon samples exhibit a limited distribution of ages. Samples NIG164 and 568 (both with catchment areas dominated by Older Granite) and 1633 (with migmatitic gneisses and Older Granites as the main bedrock lithologies in the catchment area) exhibit large populations at $c .600 \mathrm{Ma}$ with minor components representing older ages. 
NIG-568 (Figs. 9a and b) exhibits significant maxima at $635 \mathrm{Ma}$ with other concordant grain ages at 780 and 875Ma. NIG-1633 exhibits an almost unimodal distribution (Figs. 10a-c) with a key maxima at $600 \mathrm{Ma}$, but with minor components at $650 \mathrm{Ma}$ and $790 \mathrm{Ma}$ and indications of older material up to $c .2150 \mathrm{Ma}$. NIG-164 shows a very similar distribution (Figs. 11a-c) to NIG-1633 with older components up to $c .2150$ Ma but with its key maxima at $640 \mathrm{Ma}$ with more significant maxima at $790 \mathrm{Ma}$. Other minor maxima are present at 590, 720, 1075, 1120 and 1300 Ma. NIG-78 shows a very different distribution (Figs. 12a and b) to the other three samples indicating its derivation from a catchment dominated by older, migmatitic gneisses and with no Older Granite intrusions. This sample clearly has a greater component of older zircons which have been disturbed by non-zero-age Pb-loss (around 500 Ma). Few points remain concordant with the majority appearing discordant from around $2 \mathrm{Ga}$ or older and clearly this sample has only minor input from c.600 Ma sources. Although highly discordant these data still indicate the relative paucity of the $600 \mathrm{Ma}$ component in this sample.

Therefore, the agreement in isotopic ages obtained from the four detrital zircon samples and the ages of the main bedrock lithologies in the catchment areas of the host stream sediments supports the conclusion that the detrital zircons are derived from the proximal bedrock and are not aeolian in origin. The 590 Ma ages reflect zircon growth during the main Pan-African metamorphic event. The 606-616 Ma dates the emplacement age of the Older Granites, and the older Proterozoic ages reflect crustal events recorded in the migmatitic gneisses. No zircons with Phanerozoic ages were found to confirm (i) the absence of any intrusions related to the Jurassic Younger Granites in the study cells, and (ii) the absence of any windtransported zircons from the main outcrop area of the Younger Granites in central Nigeria.

\section{Discussion}


It is established from the new geochronological data that the sources of high zircon (and therefore Zr) contents in Nigeria's stream sediments are the underlying Precambrian granitic and migmatitic rocks, notwithstanding the fact that these rocks have zircon/Zr concentrations close to the upper crustal average of about $240 \mathrm{mg} \mathrm{kg}^{-1}$. Therefore, secondary processes that are involved in the physical and chemical weathering of bedrock and the removal of weathered material (notably clays) in watercourses and by the Harmattan winds must explain the unusually high levels of $\mathrm{Zr}$ in fine stream sediments. The alternative possibility of windborne zircon grains being transported into the stream sediments (e.g. Moreno et al., 2006) is discounted by both the geochronology which indicates a likely origin from underlying bedrock (with no evidence of a younger component), and the morphology of the zircon grains that shows that they are not aeolian (Fig. 4).

The physical processes involved in the zircon enrichment comprise flash flooding during the monsoonal rains and winnowing by the Harmattan winds during the dry season. It is proposed that the combination of these two processes creates a near-continuous removal of the clay sized fraction leaving the heavy-mineral enriched residual stream sediments. Therefore, the anomalously high $\mathrm{Zr}$ values determined in the fine fraction $(<150 \mu \mathrm{m})$ of Nigeria's stream sediments is directly attributed to weathering processes; initially caused by chemical weathering of bedrock followed by physical weathering and removal of the least resistant and 'light' components.

A measure of the physical weathering process is the winnowing index (WI) (Garrett et al., 2005; Grunsky et al., 2009) that uses the $\mathrm{Th} / \mathrm{Al}$ ratio of the stream sediments as a surrogate for their heavy mineral to clay content. Fig. 9f of Lapworth et al. (2012) shows the spatial distribution of the winnowing index measured across the Minna Cell. This shows a NNESSW zone with relatively low winnowing indices that exactly coincides with the zone of relatively low $\mathrm{Zr}$ values in Fig. 6a, supporting the conclusion that physical weathering 
processes control the chemistry of Nigeria' stream sediments. Bedrock under the zone with low $\mathrm{Zr}$ values is dominated by the Zungeru Mylonites and the metavolcanic and metasedimentary rocks in the Zungeru-Birnin Gwari Schist Belt. Figure 13 shows cross-plots of $\mathrm{Th} / \mathrm{Al}$ vs. $\mathrm{Zr}$ concentration for the major rock groups in both the Minna and South-western Cells, Spearman-rank correlation coefficients are shown in the bottom right hand corner of each plot. These results show that there is a highly significant $(p \leq 0.001)$ positive correlation between $\mathrm{Zr}$ concentrations and WI irrespective of underlying geology. The strongest correlations (0.61 to 0.85$)$ are found in the sediments draining Mesozoic and metasedimentary rocks (Figs. 13a-13d), with slightly weaker correlations (0.5 to 0.62 ) for those draining the migmatitic gneisses and Older Granites (Figs. 13e-13h).

There will be a source bedrock control on the chemistry of derived stream sediments in a study area with a uniform climate (and uniform weathering conditions) in that sediments derived from rocks with low values of a particular element should have lower contents of this element than sediments derived from rocks with higher values of the same element. Bedrock under the NNE-SSW zone of relatively low $\mathrm{Zr}$ values in the Minna Cell comprises the Zungeru Mylonites, schist belt lithologies and deformed Older Granite plutons (Fig. 6a). Figure 7 shows that stream sediment derived from the Zungeru Mylonites and the schist belts do have relatively low $\mathrm{Zr}$ contents. Seven analysed samples of the Zungeru Mylonites (quartzofeldspathic lithologies) have between 60 and 447 ppm $\mathrm{Zr}$ with a mean value of 217 ppm $\mathrm{Zr}$ (Ajibade et al., 2006) which is below the crustal average for zirconium. Published whole rock analyses of schist belt rocks from the Minna Cell are confined to seven analysed felsic metavolcanics (Ajibade et al., 2006). These have a mean $\mathrm{Zr}$ content of $326 \mathrm{ppm}$. As there is no mention by Ajibade et al. (2006) of zircon as an accessory phase in any of the schist belts' metasedimentary lithologies it would suggest that the overall $\mathrm{Zr}$ content of the schist belts is low. 
Whole rock analyses of the two Older Granite samples (143-PP3 and R-1303) from within the zone of low $\mathrm{Zr}$ values in the Minna Cell have $\mathrm{Zr}$ values of 217 and $163 \mathrm{ppm}$ respectively. These are low compared to a mean value of $455 \mathrm{ppm} \mathrm{Zr}$ for the migmatitic gneisses and 362 ppm Zr for the Older Granites of the South-western Cell. Published Zr contents of the other rock units (Table 2) show a similar range of values and this is reflected in the similarities in the range of $\mathrm{Zr}$ values in stream sediments derived from these rocks (Fig. 7).

The highest $\mathrm{Zr}$ values in the stream sediments of the Minna Cell are mostly found in the SE quadrant which is underlain by the migmatitic gneisses and Older Granite plutons (mainly the Suleja Batholith). This is reflected in the high $\mathrm{Zr}$ values for the migmatitic gneisses shown in Fig. 7. The lower $\mathrm{Zr}$ values for stream sediments derived from the Minna Cell's Older Granites in Fig. 7 are due to the low values over the western Older Granites. This would suggest that there are regional whole rock chemistry differences in the Older Granite Suite. The fact that the substantial number of enriched outliers shown in the $\mathrm{Zr}$ values for the Older Granite in the Minna Cell in Fig. 7 are found over specific plutons (notably the Suleja Batholith) supports this conclusion. Similarly, the high $\mathrm{Zr}$ outliers in the migmatitic gneisses from the Minna Cell shown in Fig. 7 are also from the SE quadrant of the Cell (Fig 6a). There is a genetic link between the Older Granites and the migmatitic gneisses in that the granites are crustal melts of the gneisses and will therefore inherit some of the chemical characteristics of their source rocks.

The $\mathrm{Zr}$ values in the stream sediments draining the migmatitic gneisses. Older Granites and Metasedimentary and Metavolcanic units in the South-western Cell are generally higher than in the stream sediments draining these units in the Minna Cell (Fig. 7). This may solely be due to the fact that the winnowing indices in the South-western Cell are generally higher than those in the Minna Cell, as shown in Fig. 9f of Lapworth et al. (2012). There may also be a bedrock control if the $\mathrm{Zr}$ contents of the same bedrock units are lower in the Minna Cell. 
Unfortunately, the scarcity of rock geochemical data means that it is difficult to specifically comment on any bedrock control. The few whole rock analyses of the Older Granites do suggest that there is possibly a considerable difference in the $\mathrm{Zr}$ contents of the Older Granites from the Minna Cell (mean Zr of $171 \mathrm{ppm}$ ) compared to the Older Granites from the South-western Cell (mean $\mathrm{Zr}$ of $362 \mathrm{ppm}$ ). If this is the case, and if there are similar differences in the chemistry of the migmatitic gneisses and metasedimentary and metavolcanic rocks, there may be a terrane boundary within the Pan-African of Nigeria with the boundary concealed beneath the NW-SE Bida Basin. Significant differences in stream sediment rare earth element composition between the two Cells for these major rock types also suggest that there may be bedrock controls (Lapworth et al., 2012).

As elements concentrated in resistant 'heavy' minerals such as zircon are preferentially concentrated in Nigerian stream sediments it means that anomalously' high values of elements such as $\mathrm{Zr}$, rare earth elements (REEs) and precious metals in stream sediments do not necessarily indicate the presence of potential bedrock mineralisation for these elements in the catchment areas of the collected stream sediment samples. However, the weathering process found in Nigeria favours the development of placer deposits of 'heavy minerals', for example the economic placer deposits of tin (cassiterite) derived from the weathering of the Younger Granites found in the Jos area.

Zirconium concentrations (in non-aeolian zircon grains) in lithified, fine-grained, fluvial sedimentary rocks may also provide a clue to palaeo-climates during sedimentation. If these rocks are found to contain high $\mathrm{Zr}$ values comparable to those reported from modern Nigeria stream sediments it could indicate that the original sediments were deposited in water courses susceptible to flash flooding in a tropical environment comparable to present-day SubSaharan West Africa.

\section{Conclusion}


Compared to a range of published regional stream sediment studies elsewhere in Africa, Asia (e.g. Chandrajith et al., 2000, 2001; Key et al., 2004) and Europe (Salminen et al., 2005), the Nigerian stream sediments show comparatively high concentrations for Zr. Central and SW Nigeria has a tropical/sub-tropical climate, with a monsoon season causing flash flooding, and a 'dry' season characterised by the Harmattan winds that blow SSW across the country from the Sahara Desert. Floodwaters are channelled in the well-developed dendritic feeder streams into the Niger River and Atlantic Ocean and are charged with suspended clays. The Harmattan winds winnow clays from unprotected interfluves as well as from dry stream beds. This unusual combination of both a wet season characterised by tropical storms and a dry season with very strong unidirectional winds has caused the concentration of heavy minerals, including zircon in Nigeria's stream sediments.

\section{Acknowledgements}

The paper is published with the permission of the Professor Siyan Malomo, Director General of the Nigerian Geological Survey Agency (NGSA) and the Professor John Ludden, Executive Director of the British Geological Survey (BGS, NERC). Thanks are given to Nick Roberts of NIGL for running some of the laser ablation U-Pb analyses on the AttoM. John Wheeler, Paul Turner and Kay Green (BGS) are thanked for overseeing sample preparation, GIS and analytical aspects of the work. The authors thank Bob Garrett and Laurence Robb for reviewing and improving the manuscript. The authors thank the large number of NGSA and Nigerian University staff involved in the fieldwork.

\section{References}

Adekoya, J.A., 1996. The Nigerian Schist Belts: Age and depositional environment. Implications from associated banded iron-formations. Journal of Mining and Geology, 32, 35-46.

Adeleye, D.R., 1974. Sedimentology of the fluvial Bida Sandstone (Cretaceous), Nigeria. Sedimentary Geology, 12(1): 1-24. 
Ajibade, A.C., Wright, J.B., 1989. The Togo-Benin-Nigeria Shield: evidence of crustal aggregation in the Pan-African belt. Tectonophysics, 165 (1-4), 125-129.

Ajibade, A.C., Fitches, W.R., Wright, J.B., 1979. The Zungeru mylonites, Nigeria: recognition of a major tectonic unit. Revue Géologie Dynamique et Géographie Physique, 21, 359-363.

Ajibade, A.C., Woakes, M., Rahaman, M.A., 1987. Proterozoic crustal development in the Pan-African regime of Nigeria In: Proterozoic lithospheric evolution. 259-271 In: Kröner, A. (editor). (American Geophysical Union.)

Ajibade, A.C., Anyanwu, N.P.C., Okoro, A.U., Nwajide, C.S ., 2008. The geology of the Minna area. Bulletin, Nigerian Geological Survey Agency, 43, 112pp.

Black, R., 1980. Precambrian of West Africa. Episodes, no. 4, (Dec.): 3-8.

Bowden, P., Kinnaird, J.A., 1984. Geology and Mineralization of the Nigerian Anorogenic Ring Complexes. Geologisches Jahrbuch, B56, 3-65.

Burke, K.C., Dewey, J.F., 1972. Orogeny in Africa. In: Dessauvagie TFJ, Whiteman, AJ (eds), Africa geology. University of Ibadan Press, Ibadan, 583-608.

Chandrajith, R., Dissanayake, C.B., Tobschall, H.J., 2000. The stream sediment geochemistry of the Walawe Ganga Basin of Sri Lanka - implications for Gondwana mineralisation. Gondwana Research, 3 (2), 189-204.

Chandrajith, R., Dissanayake, C.B., Tobschall, H.J., 2001. Application of multi-element relationships in stream sediments to mineral exploration: a case study of Walawe Ganga Basin, Sri Lanka. Applied Geochemistry, 16 (3), 339-350.

Dada, S.S., 2006. Proterozoic evolution of Nigeria. In: The basement complex of Nigeria and its mineral resources (A Tribute to Prof. M.A. Rahaman). 29-44. In. Oshi, O. (editor). (Akin Jinad \& Co. Ibadan.)

Darnley, A.G., Bjorklund, A., Bolviken ,B., Gustavsson, N., Koval, P. V., Plant ,J.A., Steenfelt, A., Tauchid, M., Xuejing, Xie., 1995. A global geochemical database for environmental and resource management. 19, (Paris: UNESCO publishing.)

De Swardt, A.M.J., Vine, H., 1953. The geology of the country around Ilesha. Bulletin, Geological Survey of Nigeria, 23, 54pp.

Dempster, A.N., 1966. 1:250 000 geological map of Sheet 61 (Akure). Geological Survey of Nigeria. Falconer JD 1911. The geology and geography of northern Nigeria. (London: Macmillan.)

Ferré, E.C., Déléris, J., Bouchez, J-L., Lar, A.U., Peucat, J-J., 1996. The Pan-African reactivation of contrasted Eburnean and Archaean provinces in Nigeria: structural and isotopic data. Journal of the Geological Society of London, 153, 719-728.

Ferré, E.C., Caby, R., Peucat, J.J., Capdevila, R., Monié, P., 1998. Pan-African, postcollisional, ferro-potassic granite and quartz-monzonite plutons of Eastern Nigeria. Lithos, 45(1-4), 255-279.

Fitches, W.R., Ajibade, A.C., Egbuniwe, I.G., Holt, R.W., Wright, J.B., 1985. Late Proterozoic Schist Belts and plutonism in NW Nigeria. Journal of the Geological Society of London, 142 (2), 319-337.

Fookes, P.G., 1997. Tropical Residual Soils. Geological Society Publishing House, Bath, UK, 184 pp.

Garrett, R.G., Drew, L.J., Sutphin, D.M., 2005. Estimating soil geochemistry from stream sediment geochemistry. In: GIS and Spatial Analysis: Proc. 2005 Annual Conference, International Association for Mathematical Geology (IAMG), 1, 452-457.

Grant, N.K., 1967. Complete Late Pre-Cambrian to Early Palaeozoic Orogenic Cycle in Ghana, Togo and Dahomey. Nature, 215(5101), 609-610.

Grant, N.K., 1969. The geochronology of Precambrian basement rocks from Ibadan southwestern Nigeria. Earth, Planetary Science Letters, 10 (1), 29-38. 
Grant, N.K., 1978. Structural distinction between a metasedimentary cover and an underlying basement in the 600-m.y.-old Pan-African domain of northwestern Nigeria, West Africa. Geological Society of America Bulletin, 89 (1), 50-58.

Grant, N.K.M., Hickman, M., Burkholder, F.R., Powell, J.L., 1972. Kibaran metamorphic belt in Pan-African domain of West Africa? Nature (Physical Science), 238, 90-91.

Grunsky, E.C., Drew,L.J., Sutphin,D.M., 2009. Process recognition in multi-element soil and stream-sediment geochemical data. Appl. Geochem. 24, 1602-1616.

Guiraud, M., 1990. Tectono-sedimentary framework of the early Cretaceous continental Bima formation (upper Benue Trough, NE Nigeria). Journal of African Earth Sciences (and the Middle East), 10 (1-2), 341-353.

Hillier, S., Susuki, K., Cotter-Howells, J., 2001. Quantitative determination of Cerussite (lead carbonate) by X-ray powder diffraction and inferences for lead speciation and transport in stream sediments from a former lead mining area of Scotland. Applied Geochemistry, 16 (6), 597-608.

Hockey, R.D., Jones, H.A., Carter, J.D., 1963. Sheet 59: 1:250,000 Ibadan geological map. Geological Survey, Nigeria. Kaduna.

Iloeje, N.P., 1991. A New Geography of Nigeria. Academy Press Ltd., Lagos. 201pp.

Jacobson, R.R.E., Snelling, N.J., Truswell, J.F., 1964. Age determinations in the geology of Nigeria with special reference to the Old and Younger Granites. Overseas Geology and Mineral Resources, 9, 168-182.

Jaffey, A. H., Flynn, K. F., Glendenin, L. E., Bentley, W. C., and Essling, A. M., 1971, Precision measurements of half-lives and specific activities of ${ }^{235} \mathrm{U}$ and ${ }^{238} \mathrm{U}$ : Physics Reviews, C4, p. 1889-1906.

Jones, H.A., Hockey, R.D., 1964. The geology of parts of South-western Nigeria. Bulletin, Geological Survey of Nigeria, 31, 101pp.

Kemp, S.J., Wagner, D., Mounteney, I., 2011. Mineralogical analysis of heavy minerals from stream sediments, Nigeria. British Geological Survey Internal Report, IR/11/008. 18pp.

Key, R.M., De Waele, B., Liyungu, A.K., 2004. A multi-element baseline geochemical database from the western extension of the Central African Copperbelt in north western Zambia. Trans. Inst. Min. Metall. B, Appl. Earth Sci. 113, 205-226.

Key, R.M., Johnson, C.C., Lapworth, D.J., Knights, K.V., 2010. Final report Nigerian Geochemical Mapping Technical Assistance Project. British Geological Survey. Commissioned Report, CR/10/056. 188pp.

King, B.C., de Swardt, A.M.J., 1949. The geology of the Osi area, Ilorin Province. Bulletin, Geological Survey of Nigeria, 20, 93pp.

The whole complex is cut by microgabbroic dykes.

Kröner, A., Ekwueme, B.N., Pidgeon, R.T., 2001. The Oldest Rocks in West Africa: SHRIMP Zircon Age for Early Archean Migmatitic Orthogneiss at Kaduna, Northern Nigeria. Journal of Geology, 109, 399-406.

Lancelot, J.R., Rahaman, M.A., 1983. A propos de l'evenement a 1000 Ma en Afrique occidentale: ${ }^{\circ} /$ L'orthogneiss d'Ilfe-Ife (Nigeria). C. R. Somm. Soc. Géol. Fr. (Page unknown).

Lapworth, D.J., Knights, K.V., Key, R.M., Johnson, C.C., 2010. The regional geochemistry of the South-western Master Cell, Nigeria: a summary report. Nigerian Geochemical Mapping Technical Assistance Project. British Geological Survey Commissioned Report CR/10/053. 114pp.

Lapworth, D.J., Knights, K.V., Key, R.M., Johnson, C.C., Ayoade, E., Adekanmi, M.A., Arisekola, T.M., Okunlola, O.A., Backman, B., Eklund, M., Everett, P.A., Lister, T.R., Ridgway, J., Watts, M.J., Kemp, S.J., Pitfield, P.E.J., 2012. Geochemical mapping using stream sediments in west-central Nigeria: implications for environmental studies and 
mineral exploration in West Africa. Applied Geochemistry, doi:10.1016/j.apgeochem.2012.02.023

Malomo, S., 2004. National Geological Map of Nigeria, scale 1:2,000,000. Nigerian Geological Survey Agency. Abuja, Nigeria.

Malomo, S., 2006. National Geological Lineaments Map of Nigeria. 1:2,000,000. Nigerian Geological Survey Agency. Abuja, Nigeria.

McCurry, P., 1971. Pan-African Orogeny in Northern Nigeria. Geological Society of America Bulletin, 82(11), 3251-3262.

Moreno, T., Querol, X., Castillo, S., Alastuey, A., Cuevas, E., Herrmann, L., Mounkaila, M., Elvir, J., Gibbons, W., 2006. Geochemical variations in Aeolian minerals from the SaharaSahel Dust Corridor. Chemosphere, 65 (2), 261-270.

Obaje, N.G., 2009. Geology and Mineral Resources of Nigeria. Springer-Verlag, Dordrecht, Heidelberg, London, New York.

Odeyemi, I.B., 1981. A review of the orogenic events in the Precambrian basement of Nigeria, West Africa. Geologische Rundschau, 70 (3), 879-909.

Odigi, M.I., 2002. Geochemistry and geotectonic setting of migmatitic gneiss and amphibolites in the Okene-Lokoja area of south-western Nigeria. Journal of Mining Geology, 38(2): 81-89.

Ogezi, A.E.O., 1977. Geochemistry and Geochronology of basement rocks from northwestern Nigeria (Unpublished Ph.D. thesis). University of Leeds, England. 295 pp.

Rahaman, M.A., Emofurieta, W.O. 1983. The potassic-granites of the Igbeti area: further evidence of the polycyclic evolution of the Pan-African belt in southwestern Nigeria. Precambrian Research, 22 (1-2), 75-92.

Rahaman, M.A., Lancelot, J.R., 1984. Continental crust evolution in SW Nigeria: constraints from U/Pb dating of pre-Pan-African gneisses. In: Rapport d'activite 1980-1984 Documents et Travaux du Centre Geologique de Montpellier, 4, 41.

Rollinson, H.R., 1993. Using geochemical data: evaluation, presentation, interpretation. Longman group, UK. 352pp.

Russ, W., 1957. The geology of parts of Niger, Zaria and Sokoto Provinces with Special Reference to the Occurrence of Gold. Bulletin, Geological Survey of Nigeria, 27, 42pp.

Salminen, R., Batista, M.J., Bidovec, M., Demetriades, A., De Vivo, B., De Vos, W., Duris, W., Gilucis, A., Gregorauskiene, V., Halamic, J., Heitzman, P., Lima, A., Jordan, G., Klaver, G., Klein, P., Lis, J., Locotura, J., Marsina, K., Mazreku, A., O’Connor, P.J., Olsson, S.A., Petersel, V., Plant, J.A., Reeder, S., Salpeteur, I., Sandstrom, H., Siewers, U., Steenfelt, A., Tarvainen, T., 2005. Geochemical atlas of Europe. Part 1, Background information, methodology and maps. Espoo, Finland: Geological Survey of Finland. ISBN 9516909213.

Shibayan, Y., 1990. Field evidence for the ophiolitic nature of the serpentinites in the Proterozoic supracrustal of NW Nigeria. 123-128. In: Recent data in African Earth Sciences. Rocci, G. and Deschamps, M. (editors).

Snyder, R.L., Bish, D.L., 1989. Quantitative analysis. In: Bish, DL, Post, JE (Eds), Modern Powder Diffraction, Reviews in Mineralogy, Volume 20, Mineralogical Society of America, USA, 101-144 (Chapter 5).

Stacey, J.S., Kramers, J.D., 1975. Approximation of terrestrial lead isotope evolution by a two-stage model. Earth and Planetary Science Letters, 26: 207-221.

Thomas, R.J., Jacobs, J., Horstwood, M.S.A., Ueda, K., Bingen, B., Matola, R., 2010. The Mecuburi and Alto Benfica Groups, NE Mozambique: Aids to unravelling ca. 1 and 0.5 Ga events in the East African Orogen. Precambrian Research, 178, 72-90. 
Tijani, M.N., Okunlola, O.A., Abimbola, A.F., 2006. Lithogenic concentrations of trace metals in soils and saprolites over crystalline basement rocks: A case study from SW Nigeria. Journal of African Earth Sciences, 46 (5), 427-438.

Truswell, J.F., Cope, R.N., 1960. Sheet 31, 1:250,000 Kusheriki geological map. Geological Survey, Nigeria. Lagos.

Truswell, J.F., Cope, R.N., 1963. The geology of parts of Niger and Zaria Provinces, northern Nigeria. Bulletin, Geological Survey of Nigeria, 29, 104pp.

Tubosun, I.A., Lancelot, J.R., Rahaman, M.A., Ocan, O., 1984. U-Pb Pan-African ages of two charnockite-granite associations from South-western Nigeria. Contributions to Mineralogy and Petrology, 88 (1-2), 188-195.

Tugarinov, A.I., Knorre, K.G., Shanin, L.L., Prokofieva, L.N., 1968. The geochronology of some Precambrian rocks of southern West Africa. Canadian Journal of Earth Sciences, 5 (3), 639-642.

Van Breemen, O., Pidgeon, R.T., Bowden, P., 1977. Age and isotopic studies of some PanAfrican granites from north-central Nigeria. Precambrian Research, 4 (4), 307-319.

Watts, M. J., Chenery, S R., 2010. Report on results of overseas analysis: unprocessed data. Nigerian Geochemical Mapping Technical Assistance Project. British Geological Survey. Commissioned Report, CR/10/020. 60pp.

Wedepohl, K.H., 1995. The composition of the continental crust. Geochimica et Cosmochimica Acta, 59(7), 1217-1232.

Wright J.B., 1970. Controls of mineralisation in the older and younger tin fields of Nigeria. Economic Geology, 65 (8), 945-951.

\section{Table captions:}

Table 1. $\mathrm{Zr}$ results for primary and secondary reference materials

Table 2. Published $\mathrm{Zr}$ values (in $\mathrm{mgkg}^{-1}$ ) in analysed rocks from SW Nigeria; ${ }^{1} \mathrm{King}$ and de Swardt (1949); ${ }^{2}$ Tijani et al. (2006); ${ }^{3}$ De Swardt and Vine (1953) and Jones and Hockey (1964); ${ }^{4}$ range of 12 analyses in Rahaman and Emofurieta (1983)

Table 3. Summary mineralogy results for stream sediments $(<150 \mu \mathrm{m})$

Table 4. Summary mineralogy results for stream sediment heavy mineral separates

\section{Figure captions:}

Figure 1. The distribution of GRN cells in Nigeria. The shaded areas indicate the Minna Cell (N07E05) and the South-western Cell (parts of N06E03, N05EO3 and N05E04).

Figure 2. A simplified geological map of Nigeria (from Malomo 2004).

Figure 3. Simplified geology of the Minna Cell showing the locations of three dated PanAfrican granites and the locations of two stream sediments with dated detrital zircons (all labelled with their sample number). SB* refers to schist belt.

Figure 4. Photomicrograph of detrital zircons collected from the $<150 \mu \mathrm{m}$ fraction of stream sediments: a) Euhedral zircon grains (Zrn) from stream sediment sample 163, b) Anhedral and equant zircon (Zrn), monazite (Mnz) and rutile (Rt) grains from stream sediment sample 78South-western Cell.

Figure 5. Cathodoluminescence images of dated zircons from Older Granites from the Minna Cell: a) Granite sample 143-PP3, b) Granite sample 165-PP4, c) Granite sample R-1303

Figure 6. a) Stream sediment $\mathrm{Zr}$ plots in the Minna Cell as a gridded image. b) Stream sediment $\mathrm{Zr}$ plots in the South-western Cell as graduated points and showing the locations of the three dated detrital zircon samples superimposed on a simplified geology map. 
Figure 7. Box-plot of $\mathrm{Zr}$ concentrations (mg k-1, log scale) in stream sediments in the Minna and South-western Cells, Nigeria. Geological grouping on X-axis: a) Mesozoic Southwestern Cell, b) Mesozoic Minna Cell, c) Metasediments South-western Cell, d) Metasediments Minna Cell, e) Migmatitic gneiss South-western Cell, f) Migmatitic gneiss Minna Cell, g) Older Granite South-western Cell, h) Older Granite Minna Cell, i) Zungeru Mylonites Minna Cell. Horizontal lines: short dash = average Upper Crust Concentration (Wedepohl 1995), dash-dot = average Local Older Granite value (see Table 3), long dash $=$ Local metasediment value (Tijani et al., 2006), long dash grey $=$ local Zungeru Mylonites (Ajibade et al., 2008), solid grey $=$ average European stream sediment value (Salminen et al., 2005), dotted line = average Local Migmatitic Gneiss value (see Table 2). The notches represent the 95\% confidence limits around the median value for each group, outlier values are shown as open circles.

Figure 8. U-Pb Concordia plot for granite samples a) sample R-1303, b) sample 43-PP3, c) sample 165-PP4.

Figure 9. a) U-Pb Concordia plot for detrital zircon sample 568, b) histogram of determined ages for detrital zircon sample 568.

Figure 10. a) U-Pb Concordia plot for detrital zircon sample 1633, b) enlarged view of the Concordia plot for detrital zircon sample 1633 between intercept points 550 and $850 \mathrm{Ma}$, c) histogram of determined ages for detrital zircon sample 1633.

Figure 11. a) U-Pb Concordia plot for detrital zircon sample 164, b) enlarged view of the Concordia plot for detrital zircon sample 164 between intercept points 550 and $850 \mathrm{Ma}$. c) histogram of determined ages for detrital zircon sample 164.

Figure 12. a) U-Pb Concordia plot for detrital zircon sample 178, b) histogram of determined ages for detrital zircon sample 78 .

Figure 13. Cross-plots of Th/Al vs Zr for stream sediments: a) Mesozoic South-western Cell, b) Mesozoic Minna Cell, c) Metasediments South-western Cell, d) Metasediments Minna Cell, e) Migmatitic gneiss South-western Cell, f) Migmatitic gneiss Minna Cell, g) Older Granite South-western Cell, h) Older Granite Minna Cell, i) Zungeru Mylonites Minna Cell. Correlation coefficients calculated using Spearman rank method, the degree of significance indicated as follows: $* * *$ for very high significance $(\mathrm{p}<0.001)$, ** for high significance $(0.001 \leq p<0.01)$.

\section{Supplementary data:}

Table S1. A summary of the sample collecting methodology.

Table S2. ICP-MS methodology used on the $<150 \mu \mathrm{m}$ stream sediments (from Watts and Chenery 2010).

Table S3. XRD methodology used on the $<150 \mu \mathrm{m}$ stream sediments (from Kemp et al. 2011).

Table S4. Summary results from stream sediment zircon U-Pb geochronology 